\title{
ARE CHILDREN BETTER AT LEARNING LANGUAGES THAN ADULTS?
}

\author{
Syafiyah
}

Ketua Jurusan Bahasa dan Sastra Inggris

Fakultas Humaniora dan Budaya, Universitas Islam Negeri (UIN) Malang.

Jalan Gajayana No. 50 Telepon (0341) 570872, Faksimile (0341) 570872 Malang 65144.

\begin{abstract}
Abstrak
Usia merupakan faktor yang mempengaruhi keberhasilan dan kegagalan dalam akuisisi bahasa kedua. Secara umum diasumsikan bahwa anak-anak merupakan pembelajar bahasa yang baik dibanding orang dewasa. Tulisan ini akan membahas beberapa teori tentang permasalahan di atas. Secara teoretis ada beberapa faktor yang mempengaruhi kemampuan akuisisi bahasa kedua, yaitu: neurology, psikomotor, afektif, kognitif, dan input. Teori-teori di atas secara umum mengklaim bahwa anak-anak memiliki peluang yang lebih besar untuk akuisisi bahasa kedua dibanding orang dewasa. Meskipun demikian, ada temuan yang menunjukkan bahwa orang dewasa karena faktor kognitifnya menjadi lebih baik dalam hal kemampuan akuisisi bahasa kedua dibanding anak-anak. Hal ini terjadi terutama dalam hal sintaksis dan morpologi.
\end{abstract}

Kata Kunci

Anak, Akuisisi, Bahasa Kedua, Sintaksis, Morpologi, Neurologi

\section{Introduction}

Age has been attributed as a factor that contributes to success or failure in second language acquisition (SLA). It is generally assumed that children are better language learners than adults. This assumption 
is derived from cases in which, when adults and children come to a target language country or are exposed to L2 in a target language community, children seem to acquire the target language more perfectly. Is this phenomenon due to age difference, which means that the younger the learner, the better he/she will be?

This paper will come up with some theoretical views dealing with this issue. Such factors as neurological, psychomotor, cognitive, affective, emotional, and input factors are addressed to to explain the age-related differences of SLA.

\section{Neurological Factor}

The notion of age as a factor that determines second language (L2) acquisition is mostly based on the belief that there is a critical period for L2 learning, during which time the language can be acquired more easily. The critical period hypothesis is generalized from the findings of neurological research which support that lateralization -in which particular functions, such as intellectual, analytical, and language functions begin to be concentrated on the left hemisphere and the emotion, social-related needs are assigned to the right hemisphere, occurs with the maturity of the brain. (Brown, 1987)

With regard to the relationship between lateralization and language acquisition, Penfield and Roberts, as cited by Ellis (1985), suggest that this lateralization results in the decrease of brain plasticity, since the neurological capacity of learning language which at the beginning involves both left and right hemispheres is eventually centered on the left hemisphere. This neurological change is then believed to be the direct cause of adults' difficulty in L2 learning.

If lateralization is considered to be closely related to L2 learning, when then does it take place? With respect to this issue, there are different opinions among neurological researchers. Lenneberg (1967) believes that lateralization occurs from age 2 until the age of puberty. Geschwind (Brown, 1987), however, suggests that lateralization occurs in much earlier age, while Krashen (Brown, 1987), in line with Scovel 
(Brown, 1987), argues that lateralization has been completed by around the age of 5 .

If there is no convincing agreement about the age at which lateralization takes place, does it still mean that lateralization determines L2 acquisition? Given the end view of lateralization being complete at age 5 , is it impossible to acquire a language after this age? If lateralization is completed by the age of puberty, can it be concluded that a second language is difficult to acquire after puberty?

Another neurological explanation is given by Seliger (1978) using a multiple critical period hypothesis or different sensitive periods. He claimed that the ability to acquire second language skills declines abruptly or gradually with a loss of plasticity caused by other aspects of cerebral maturation unrelated to lateralization, which include myelination, thickening of the corpus callosum, and intrahemispheric specialization or localization of function.

Of those factors, myelination has been regarded as particularly interesting to explain. Myelination is "the process during which the axon projections of many neurons undergo anatomical and chemical changes as they are wrapped in myelin sheats consisting of lipids and proteins, something that begins in the fetus and takes several decades to complete" (Long, 1990). Completion of myelination is interpreted as functional maturation of the brain, resulting in neural space committed in an invariable path. The process is implicated in the decline of the language learning capacity, and different aspects of language are affected at different stages. The first maturational constraint affecting phonology occurs around the age of 5 or 6 , and the critical period affecting grammar acquisition or morphology and syntax happens around the age of 15 (Long, 1990)

However, the explanation of plasticity loss as a function of the myelination process also raises some problems. It is considered speculative since, in general, the evidence linking cerebral dominance and age differences in learners is not clear (Ellis, 1986). Moreover, it is based largely on pathological evidence generalized to normal 
populations. It is absolutely dangerous to extrapolate from the abnormal to the normal brain. Hence, the relevance of the notion of plasticity in non-insult situations is still doubtful? (Long, 1990)

It seems that neurological explanation in itself is not adequate to explain the existence of critical periods in SLA. There are some other factors which can be taken into account, one of which is psychomotor factor which will be discussed in the following section.

\section{Psychomotor Factor}

This factor deals with the role of the psychomotor coordination of the speech muscles in SLA which shapes accent. Human beings are equipped with hundreds of muscles which are used in the articulation of human speech such as throat, larynx, mouth, lips, and tongue. A high degree of muscular control is required to acquire native-like fluency of speaking. At birth, the speech muscles are developed only to the extent that the larynx can control sustained cries. Gradually, these speech muscles develop. The control of some complex sounds such as ' $r$ ', however, is frequently not achieved until after age 5 . Thus, children who acquire a second language after 5 is believed to have a physical advantage in that phonemic control of a second language is physically possible while the plasticity is still present (Brown, 1987).

Some research findings referred to by Brown (1987), Flege (1999), and Bongaerts (1999) have proved that beyond the age of puberty people do not usually acquire authentic or native-like pronunciation of the second language. Instead, they tend to speak their second language with a foreign accent. With regard to this fact, Brown argues that it cannot be explained merely by lateralization of the brain. Just as other physical skills requiring muscular dexterity -athletics, for instancespeech, in particular the pronunciation, will be acquired more perfectly if it is learned at a young age, due to the fact that pronunciation involves the control of so many muscles. Scovel (Bongaerts, 1988) asserts that pronunciation is the only aspect of language that has neuromuscular basis, requires neuromotor involvement, and has a 
physical reality. On these grounds, starting learning a second language earlier is considered advantageous.

However, it is important to note, that pronunciation of a language is neither the only nor the most important criterion for acquisition. Hence, people who have fluent control of a second language, but do not have perfect pronunciation and native-like accent cannot be accounted as not proficient in the second language. The acquisition of the communicative and functional purposes of a language is much more crucial.

\section{Cognitive Factor}

Cognitive theory is concerned with intellectual development of human beings. According to Piaget (Brown, 1987), intellectual development of a child goes through various stages, the sensomotor stage (0-2), the pre-operational stage (2-7), and the operational stage (7$16)$, with a crucial change from the concrete operational stage to the formal operational stage around the age of 11. Based on Piaget's division, the most considerable stage for second language acquisition seems to occur at puberty or within the operational stage, during which time a person begins to develop capability of formal abstract thinking and analysis.

The development of abstract thinking ability, according to Rosansky (Els et al., 1987), allows people learning language to work out rules. They are more able to compare both similarities and differences between L1 and L2. They are also able to think flexibly and create their own theories about L2. They become increasingly decentered, and therefore possess a strong meta-awareness. Consequently, these may serve as blocks to natural language acquisition, forcing the learner to treat the acquisition task as a problem to be solved using his 'hypothetico-deductive logic'.

Young children, on the contrary, see only similarities, lack flexible thinking and are more self-centered. These are the pre-requisites of automatic language acquisition. Moreover, young children do not 
realize that they are acquiring language. They also have not developed social attitudes towards the use of one language as opposed to another. That is why they are cognitively open to another language. This belief supports the idea that post puberty learners are less efficient and less successful than younger learners. It, hence, highlights the existence of critical period hypothesis from the cognitive perspective.

However, in contrast to the above theory, there is an argument that greater cognitive maturity and greater learning experience on the part of the older language learners are assets (Stern, 1983). The cognitive advantages of adults take place especially in formal language learning situations, since they possess a greater memory storage capacity for analytic reasoning and can develop a strong instrumental motivation, qualities which can lead to very effective learning (Els, et al., 1987). Supporting this idea, Taylor (Dulay and Burt, 1982) makes the point that adults' cognitive maturity allows them to deal with the abstract nature of language better than children. This is more as adults' cognitive superiority than their cognitive deficiency. In line with this, Genesee (Dulay and Burt, 1982), citing several studies indicating a superior rate of L2 achievement in classroom studies for older learners, confirms that older students tend to be more efficient learners than younger students. In particular, Ellis (1987), reviewing studies of SLA conducted by among others Remirez and Politzer, and Hoefnagel-Hohle, argues that adolescents and adults are better L2 learners than children, in the areas of morphology, syntax, and vocabulary. This supports the cognitive advantage adults possess.

We turn now to another factor which may also theoretically explain children-adults differences.

\section{Affective Factor}

The affective or emotional domain includes such factors as empathy, self-esteem, extroversion, inhibition, imitation, anxiety, and attitudes (Brown, 1987). One of the crucial differences between children and adults concerning L2 learning to this theory is that they have 
different attitudes towards learning a second language. Children are believed to be more adaptive since they have not had either positive or negative attitude towards another language. They do not yet possess a strong self-identity, and are, therefore, not afraid to sound ridiculous when trying and practicing the second language (Els, et al., 1987). Moreover, they are facilitated with strong integrative motivation due to the need of being accepted by their playing groups in the target language community. All of the above factors are eventually believed to be beneficial to gain better language knowledge.

Adults, on the other hand, are very different to young children. Having developed quite a strong self-identity, they are likely to be hindered by an effort of defending their identity. Guiora (Brown 1987) proposes the concept of 'language ego' to account for the identity a person develops in reference to the language he or she speaks. The language ego involves the interaction of the native language and ego development. A person's self-identity is bound up with his/her language. The language ego may account for the difficulties that adults have in learning a second language. Furthermore, as awareness of formal rules has developed, adult learners become more afraid of making mistakes and, consequently, cannot experiment freely.

However, since they are cognitively developed, adult L2 learners should have capability of solving problems. This capability allows them to analyze and then overcome the problems faced. Therefore, regarding the problem of L2 learning, they are likely to be able to seek alternative approaches to learning the second language by making use of their knowledge of formal rules and conscious learning. . With respect to affective domain, therefore, Children and adults may employ different strategies which are not necessarily one is better than the other.

\section{Input Factor}

Linguistic input received by children and adults has also been regarded as one of the potential factors to explain age-related differences in rate and ultimate attainment. 
Long (1990) distinguishes between type of input and amount of input. In terms of the type of input, Long (Long, 1990, Long and LarsenFreeman, 1991), citing Hatch (1977), suggests that younger learners, especially young children receive better tuned, linguistically less complex input with more and clearer samples from which to learn the syntax of target language. The language used to communicate with children is usually modified in such a way that it becomes simpler and shorter which eventually eases them to take in the input. Furthermore, children also enjoy opportunities for language play with their nativespeaking peers, through which they get phonological practice. Concerning the amount of input, it is claimed that younger learners usually receive a larger amount of input. Based on this assumption Snow (Long, 1990) believes that adults are better at SLA on less input.

This belief, nevertheless, is doubtful for many studies reported among others by Pavesi, Schmidt, and Swain (Long, 1990) have proved that adult learners (and many children) with prolonged access to input do not, in fact, attain target levels. Thus there is no direct correlation between amount of input and second language acquisition.

\section{Concluding Remarks}

It is a matter of fact that there are age-related differences in second language acquisition. The differences have been related to the linguistic aspects the learner acquires, the rate of acquisition, and the ultimate attainment. In this paper, such differences have been explained in terms of neurological, psychomotor, cognitive, affective, and input consideration. These theories, in general, claim that children seem to have a greater capacity to learn a second language better than adults. However, some reseach findings have proved that to some extent adults appear to outperform children especially in the acquisition of morphology and syntax. This is possibly due to adults' cognitive advantage. Thus, the generalization that children are better language learners than adults is still questionable. $\square$ 


\section{BIBLIOGRAPHY}

Bongaerts, Theo. 1999. "Ultimate Attainment in L2 Pronunciation: The Case of Very Advanced Late L2 Learners", in Birdsong, David (Ed.). Second Language Acquisition and the Critical Period Hypothesis. New Jersey: Lawrence Erlbaum Associates

Brown, H. Douglas. 1987. Principles of Language Learning and Teaching. New Jersey: Prentice hall

Dulay, Heidi, Burt, Marina and Krashen, Stephen. 1982. Language Two. New York: Oxford University Press

Ellis, Rod. 1986. Understanding Second Language Acquisition. Oxford: Oxford University Press

Els, Van, Theo, et al. 1987. Applied Linguistics and the Learning and Teaching of Foreign Languages. Edward Arnold

Flege, e, James. 1999. "Age of Learning and Second Language Speech", in Birdsong, David (Ed.). Second Language Acquisition and the Critical Period Hypothesis. New Jersey: Lawrence Erlbaum Associates

Lenneberg, E. 1967. Biological Foundations of Language. New York: John Wiley \& Sons

Long, H, Michael. 1990. "Maturational Constraints on Language Development. Studies", in Second Language Acquisition. Vol. 12: 251 285.

Long, H, Michael and Larsen-Freeman, Diane. 1991. An Introduction to Second Language Acquisition Research. New York: Longman

Stern, H, H. 1983. Fundamental Concepts of Language Teaching: Oxford: Oxford University Press.[] 